\title{
Analysis of Factors Influencing Creative Personality of Elementary School Students
}

\author{
Jongman Park ${ }^{1}$, Minkee Kim ${ }^{2} \&$ Shinho Jang ${ }^{1}$ \\ ${ }^{1}$ Department of Science Education, Seoul National University of Education, Seoul, Republic of Korea \\ ${ }^{2}$ Korea Invention Promotion Association, Seoul, Republic of Korea \\ Correspondence: Shinho Jang, Department of Science Education, Seoul National University of Education, Seoul, \\ Republic of Korea. Tel: 82-2-3475-2463. E-mail: shjang@snue.ac.kr
}

\author{
Received: October 26, $2016 \quad$ Accepted: November 30, $2016 \quad$ Online Published: April 29, 2017 \\ doi:10.5539/ies.v10n5p167 URL: https://doi.org/10.5539/ies.v10n5p167
}

\begin{abstract}
This quantitative research examined factors that affect elementary students' creativity and how those factors correlate. Aiming to identify significant factors that affect creativity and to clarify the relationship between these factors by path analysis, this research was designed to be a stepping stone for creativity enhancement studies. Data were gathered from 208 students in 3 fifth-grade classes and 3 sixth-grade classes in 5 different schools located in Seoul, Korea. Survey questions, asked through five-score Likert-scale items, focused on attentiveness in science class, creativity and scientific attitude, which has been shown by the literature to have positive influences on one another. The findings include that their scientific attitude, attentiveness, and creativity correlated with significance, where gender did not have an effect on the relationship. Gender and age of the students have shown no significant effect on their scientific attitude, attentiveness or creativity. Scientific attitude, attentiveness and creativity have demonstrated positive effects to each other, the effect being stronger from scientific attitude to creativity (0.659) than the other two, attentiveness \& scientific attitude $(0.32)$ and attentiveness \& creativity (0.368). Scientific attitude affects creativity most directly (0.659), and attentiveness would affect creativity more as a cofactor next to the scientific attitude $(0.213)$ rather than when it's by itself (0.154). That is, if a teacher devises a certain way to enhance attentiveness of students during their science class, their scientific attitude and attentiveness would increase, giving them a solid chance to enhance their creativity consequently.
\end{abstract}

Keywords: creativity, scientific attitude, concentrating ability, path analysis, principal contents analysis, science education, elementary

\section{Introduction}

\subsection{Introducing the Problem}

Creativity is a key concept in many national science curriculums to promote individual's learning process and integrate knowledge with concepts. In fact, creativity is considered as the next generation standard for learning process, as many US high schools highlight students' activities with creativity as one of the main concepts of course curriculums. "Science is a result of human endeavors, imagination and creativity (HS-ESS3-3)" (NGSS Lead States, 2003, p. 288). Starting with the Vol.5 of Korean national science curriculum, the science education system in Korea has depicted creativity as the major theme in terms of acquiring problem solving skills and building interest in the subject (NCIS, 1987).

In another word, creativity is finally being appreciated as a method rather than a mere concept to complete individual education (Torrance, 1995). Our contemporary society is fluctuating at a fast pace and the change becomes more significant as time goes by. Under such situation, we need people who are capable of creating novel ideas or putting new knowledge into practical use (Yoo \& Lee, 2012). Creative individuals are not only critical parts of the basis for economic development in the 21st century (Becker, 2009), but fostering creative people also leads to a requisition to manage the fluctuating society toward a knowledge-based society which will facilitate our competitive strengths, granting us an edge.

In the literature, creative people have been considered as being distracted or not inclined to concentrate on a task (Eysenck, 1993; Mendelsohn, 1976). Their predominant view is that the disposition of creativity is inherited and 
permanently established (Eysenck, 1993; Weisberg, 1986). Those who believe that creativity is innate and does not improve by any endeavor would regard the disposition of creativity as a biological factor rather than a result of education.

According to a recent survey, however, creative people are good at changing the degree of attentiveness depending on the kind or character of task (Vartanian, 2009). Disposition of creativity can be improved by adequate education and training (Scott, Leritz, \& Mumford, 2004; Torrance, 1972). In the perspective of creativity education, most children have potential for improvement and are capable of exhibiting their creativity as long as they get well managed education that offers different design for each of their types and level (Treffinger, Isaksen, \& Stead-Dorval, 2006).

\subsection{Research Questions}

Although the literature insisted student creativity is a matter of innate ability, talent, and capability (Moravcsik, 1981), others address creativity can be nurtured (Mellou, 1996; Torrance, 1972) and improved by adequate educational programs (Scott et al., 2004). Creativity might be educated and promoted as an outcome of science classes. In the field of science education, it is presumed that students' creativity is affected by the heuristic classes that facilitate their development of cognitive skills (Scott et al., 2004), content knowledge (Boden, 2001), adequate activities and strategies in science education (Hadzigeorgiou, Fokialis, \& Kabouropoulou, 2012).

The conflict between these perspectives has been the barrier of elaborative research about attentiveness and creativity. To resolve such problems, this study aims to identify the factors of creativity, and their direct and indirect relationships through path analysis based on AMOS 21. Hence, we pose the following two research questions: (1) What are the factors influencing student creativity in the science education context? (2) What is the relationship between the factors influencing student creativity? (3) Can the general creativity model apply to creativity in the science education context?

\section{Literature Review}

\subsection{The Factors Related to Creativity}

There is a wealth of research about the facts that influence creativity. In this study, we categorize those into cognitive factors and affective factors.

\subsubsection{Cognitive Factors}

Previous studies have discovered that certain kinds of training facilitate student creativity. For example, career experience among elementary students helped enhance their creativity (Jyung et al., 2012). Short cues stimulated student creativity in making activities (Prabhakaran, Green, \& Gray, 2014). Long-term writings were shown to enhance student creativity (Cho, 2006) as did science programs with space recognition (Kim, Kwon, \& Lee, 2011). The science instruction method which applies the learning cycle model applies conceptual change based on Piaget's theory of cognitive development. Application of this model has helped student to enhance their applicable level of creativity (Chung\& Park, 2004).

Furthermore, improving the level of intrinsic motivation, enhancing confidence in their creativity and teaching metacognitive strategies helped improve creativity (Nickerson, 1999).

Individual and environmental factors, such as the size of right premotor cortex (Zhu et al., 2016), selective concentration (Eysenck, 1993; Kasof, 1997; Mendelsohn, 1976; Tarver, Buss, \& Maggiore, 1979), family income, art achievement and mathematics achievement (Sung \& Kim, 2011), scope of focused attention (Vartanian, 2009), academic achievement (Getzels \& Jackson, 1962; Park \& Yoon, 2004) have been reported as being positively correlated to student creativity. Also, students' reflection influenced their creativity (Hao et al., 2016). Otherwise, students' creativity helped enhanced academic achievement (Mourgues, Tan, Hein, Elliott, \& Grigorenko, 2016; Park \& Yoon, 2004; Sung \& Kim, 2011).

\subsubsection{Affective Factors}

Among the affective factors for creativity, we should scrutinize environmental factors such as the school, parents, and colleagues. The parents' role in creating a positive atmosphere for education, encouraging curiosity and providing environments for children to learn from experts is a necessary factor in developing creativity (Csikszentmihalyi, 1999), and the mother figure's internal locus of control also affects student's creativity (Sung, 2004). Parents' socioeconomic status restricts children's experience and this affects improving their creativity (Runco, 2007). In addition, authoritative parenting style is beneficial for improving a child's creativity (Mehrinejad, Rajabimoghadam, \& Tarsafi, 2015), and academic atmosphere of schools is also related to the development of creativity (Thomas \& Berk, 1981). For factors that are conducive to realizing creativity, there are 
positive atmosphere (Politis \& Houtz, 2015), play, sense of humor, kindness, good spirit, laughter, passion, anxiety relief, active participation (Lieberman, 1965), positive self-concept, motivation, smooth relationships, freedom, lack of test and commands (Feldhusen, Speedie, \& Treffinger, 1971), and peer support (Paramitha \& Indarti, 2014).

The affective domain comprises motivational factors in addition to environmental factors. Intrinsic motivation affects creativity (Csikszentmihalyi, 1988, 1990, 1996; Kim, Chung, \& Chung, 2007; Paramitha \& Indarti, 2014), and its sub-category 'preference for challenging tasks' is a predictive factor for creativity (Kim et al., 2007). In addition to intrinsic motivation, extrinsic reward, a form of extrinsic motivation, works as a motivational tool (Amabile, 1989). In order to improve creativity, students should learn metacognitive strategies along with increased intrinsic motivation and confidence to improve creativity (Nickerson, 1999).

Among affective factors for creativity, research on factors other than motivational or environmental factors are as follows: research that stated creativity has a correlation with ego development (Workman \& Stillion, 1974), students' emotional intelligence (Park \& Yoon, 2004), sense of humor (Couturier, Mansfield, \& Gallagher, 1981), experience of immersion (Lee \& Paik, 2014), and sense of self-efficiency (Bae \& Lee, 2000). From above, sense of self-efficiency is a necessary condition for becoming a creative person (Bandura, 1995; Sternberg \& Williams, 1996).

As seen above, although affective factors on creativity are more useful in creating an environment for enhancing creativity, there are more studies on variables that have correlations with creativity in specific situations than on predictors for creativity. On the other hand, there is lack of studies on affective factors on creativity. In addition, although there are both cognitive and affective domains in situations where students study, there are only a few studies on a model that considers both cognitive and affective domains. Moreover, there have been few studies on factors related to creativity within the science class setting and particularly on factors that are conducive to enhancing students' creativity. Therefore, this study carries significance in that it explores methods that could effectively enhance students' creativity during science classes by studying factors to consider in improving student's creativity during science classes.

\section{Theoretical Model of AAC Model}

In this study, gender (GE), scientific attitude (SA) and attentiveness in science class (AS) are selected as the main factors that influence the creative personality $(\mathrm{CP})$.

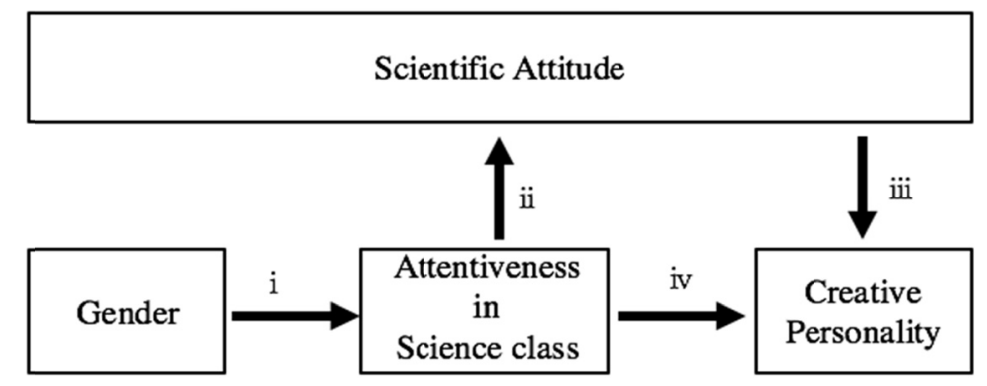

Figure 1. Theoretical model: AAC (Attitude-Attentiveness-Creative Personality) model

According to proceeding research (see Table 1), Figure 1 depicts our theoretical model and the path which could explain the direction of influence. We named this model AAC (Attitude-Attentiveness-Creative Personality).

Table 1. Hypothesis for model

\begin{tabular}{|c|c|c|}
\hline Path & Reference & Expected path \\
\hline $\mathrm{i}$ & $\begin{array}{l}\text { Response caused by inadequate stimulation occurs more frequently in boys than in girls. In addition, consistency of } \\
\text { attentiveness of boys is lower than that of girls (Kim, 2009; Lee, 2007). }\end{array}$ & $\mathrm{GE} \rightarrow \mathrm{AS}$ \\
\hline ii & $\begin{array}{l}\text { Flow }{ }^{1} \text { learning in elementary mathematic class influences academic achievement and mathematical }{ }^{2} \text { attitude (Lee, } \\
\text { 2003; Moon, 2008). }\end{array}$ & $\mathrm{AS} \rightarrow \mathrm{SA}$ \\
\hline
\end{tabular}




\begin{tabular}{ll}
\hline iii $\quad \begin{array}{l}\text { Students who had better scientific attitudes had higher elaboration scores, which is a factor of creativity, than } \\
\text { students with worse scores of scientific attitude (Kim \& Han, 2008). }\end{array}$ & SA $\rightarrow$ CP \\
\hline iv $\quad \begin{array}{l}\text { Creative people are good at changing the degree of attentiveness depending on the kind or character of task } \\
\text { (Vartanian, 2009) }\end{array}$ & AS $\rightarrow$ CP \\
& Creative performance is correlated positively with breath of attentiveness (Kasof, 1997).
\end{tabular}

Note 1. 'Flow' refers to one's mental state when he or she is completely concentrating on certain task (Csikszentmihalyi, 1990).

Note 2. The study is aiming to reveal relationship between one's scientific attitude and attentiveness. However, we were unable to obtain adequate amount of information from previously conducted studies on scientific attitude. Thus we used the relationship between attentiveness and mathematical attitude as a substitute to develop our hypothesis, since studies offered more information on mathematical attitude, and there is statistically significant positive relationship between mathematical attitude and scientific attitude (Song, 2014).

\section{Methodology}

\subsection{Participants}

The data was gathered by surveying 208 students (101 male students and 107 female students) from 3 fifth-grade classes and 3 sixth-grade classes among 5 different schools located within Seoul (see Table 2). The sample size used in this survey was over the 200 participants, which is adequate for applying the path analysis and structural equation model (Hoelter, 1983).

Table 2. Distribution of participant

\begin{tabular}{|c|c|c|c|c|}
\hline Age & Gender & Number of participants & Rate $(\%$ & \\
\hline \multirow{2}{*}{ 5th Grade } & Boys & 57 & 27.41 & \multirow{2}{*}{51.44} \\
\hline & Girls & 50 & 24.04 & \\
\hline \multirow{2}{*}{ 6th Grade } & Boys & 44 & 21.15 & \multirow{2}{*}{48.56} \\
\hline & Girls & 57 & 27.40 & \\
\hline
\end{tabular}

\subsection{Measures}

This study employed the creative personality, scientific attitude and attentiveness in science class questionnaire to gather information from elementary school students in Seoul, South Korea with a Likert-scale of 1 to 5. Before the study, a pilot test was conducted in order to clarify each item of the questionnaire. Collected responses of the questionnaire were analyzed by Principal Component Analysis (PCA). Regarding the analysis result, the questionnaire was revised to get a clear reliability (see Table 3, Table 4 and Table 5).

Table 3. Creative personality (CP) test

\begin{tabular}{lccc}
\hline Variable observed & Existing questionnaire \# & $\mathrm{M}$ & $\mathrm{SD}$ \\
\hline CP1. Confidence toward decision & 11 & 3.44 & 1.17 \\
\hline CP2. Preference of complex tasks & 05 & 3.39 & 1.18 \\
\hline CP3. Will to overcome difficult tasks & 10 & 3.44 & 1.00 \\
\hline CP4. Continuous attentiveness for problem solving & 16 & 3.39 & 1.07 \\
\hline CP5. Preference of tasks with deliberation & 26 & 3.25 & 1.13 \\
\hline CP6. Preference of new and difficult tasks & 21 & 3.47 & 1.26 \\
\hline CP7. Will to overcome difficulty for problem solving & 30 & 3.45 & 0.93 \\
\hline CP8. Preference of advanced tasks & 24 & 3.54 & 1.02 \\
\hline CP9. Patience for problem solving & 32 & 3.48 & 0.97 \\
\hline CP10. Dominance of relative confidence & 27 & 3.51 & 0.98 \\
\hline CP11. Patience for success in the future & 04 & 3.76 & 0.92 \\
\hline
\end{tabular}




\begin{tabular}{llll}
\hline CP12. Dominance of effort quantity & 20 & 3.45 & 0.92 \\
\hline CP13. Plan for future & 07 & 3.54 & 0.99 \\
\hline CP14. Tenacity to solve problems & 01 & 3.17 & 1.14 \\
\hline CP15. Dominating confidence relatively & 09 & 3.64 & 1.00 \\
\hline CP16. Confirmation of self-decision & 12 & 3.78 & 0.95 \\
\hline Total & & 3.46 & 0.78 \\
\hline
\end{tabular}

Note. From Shin (2010). Science personality test. The 16 out of 35 items are extracted; the eigenvalue $(\lambda)$ is 14.661 and total variance explained is 41.890 .

The mean score of creative personality (CP) was 3.46 , the standard deviation was 0.787 , the maximum value of each question was 3.78 and the minimum value was 3.17. The maximum value of standard deviation was 1.26 and the minimum value was 0.92 . Since the difference of the mean and standard deviation was negligible, it was safe to assume that there were no significant differences between questions. The means of the individual CP values pivoted on the mean following the normal distribution, which is a precondition of statistic treatment, so it had a high degree of reliability.

Table 4. Attentiveness in science class (AS) test

\begin{tabular}{lccc}
\hline Variable observed & Existing questionnaire \# & M & SD \\
\hline AS1. Attentiveness for tasks & 30 & 4.12 & 0.98 \\
\hline AS2. Attentiveness depending on changing place & 26 & 4.18 & 0.92 \\
\hline AS3. Hyperactivity level of regular day & 06 & 4.32 & 0.94 \\
\hline AS4. Attentiveness according to correct position in class & 18 & 4.00 & 1.07 \\
\hline AS5. Attentiveness according to trivial habits in class & 07 & 4.17 & 0.97 \\
\hline AS6. Attentiveness toward given tasks in class & 31 & 4.20 & 1.01 \\
\hline AS7. Attentiveness toward teaching material & 20 & 4.06 & 1.05 \\
\hline AS8. Attentiveness toward class & 22 & 3.94 & 1.06 \\
\hline AS9. Playing pranks with classmates in class & 09 & 3.63 & 1.11 \\
\hline Total & & 4.07 & 0.71 \\
\hline
\end{tabular}

Note. From Kim (2006). Learning attentiveness test (modified for this study). The 9 out of 32 items are extracted; the eigenvalue $(\lambda)$ is 12.459 and total variance explained is 38.936 .

The mean of attentiveness in science class (AS) was 4.07 and the standard deviation was 0.712 . The maximum value of each question was 4.18 , the minimum value was 3.63 , the maximum value of standard deviation was 1.11 and the minimum value was 0.92 . We made a conclusion that the difference of the mean and standard deviation between the questions was negligible, thus it meant that the difference of questions was negligible. The mean of individual AS values pivoted on the mean following the normal distribution as well, which is a precondition of statistic treatment, so it had a high degree of reliability.

Table 5. Scientific attitude (SA) test

\begin{tabular}{lccc}
\hline Variable observed & Existing questionnaire \# & M & SD \\
\hline SA1. Will of exploring new methods for problem solving & 20 & 3.62 & 1.04 \\
\hline SA2. Delaying judgments & 04 & 3.93 & 0.94 \\
\hline SA3. Will of improving given tools in class & 21 & 3.55 & 1.08 \\
\hline SA4. Confidence toward tasks given in class & 14 & 3.91 & 0.93 \\
\hline SA5. Curiosity toward novel phenomenon & 01 & 3.89 & 1.05 \\
\hline SA6. Curiosity toward given tasks in class & 03 & 3.53 & 1.14 \\
\hline
\end{tabular}




\begin{tabular}{llll}
\hline SA7. Desire of invention & 19 & 3.49 & 1.17 \\
\hline SA8. Respect of evidence and embracing failure positively & 16 & 3.61 & 1.07 \\
\hline SA9. Patient toward tasks in class & 18 & 3.83 & 1.00 \\
\hline Total & & 3.61 & 0.77 \\
\hline
\end{tabular}

Note. From Kim, Chung, and Jeong (1998). National science assessment system: scientific related affective domain (modified for this study). The 9 out of 21 items are extracted; the eigenvalue $(\lambda)$ is 8.414 , and total variance explained is 40.059 .

The mean score of scientific attitude (SA) was 3.61 and the standard deviation was 0.775 . The maximum value of each question was 3.93, the minimum value was 3.49, the maximum value of standard deviation was 1.17 and the minimum value was 0.93 . We made a conclusion that the difference of the mean and standard deviation between the questions was negligible, thus it meant that the difference between questions was negligible. The mean of the individual SA value pivoted on the mean following normal distribution too, which is a precondition of statistic treatment, so it had a high degree of reliability.

Based on the elaborated results of the questionnaire, we implemented descriptive analysis, mean comparisons and correlations to analyze characteristic of factors and relationships between factors. Through path analysis, furthermore, we revealed the cause-effect relationship and suitability of the structural equation model. Therefore, we modified the prototype structural model to be the AAC model.

\section{Results}

We used the SPSS 19.0 for PCA basic statistical analysis and the AMOS 21 for path analysis in order to clarify the actual effect of these factors on creativity. The findings were as follows: the difference of factors (SA, AS, $\mathrm{CP}$ ) depending on gender, correlations between the factors, casual relations between factors and implication of the statistical analysis.

\subsection{Descriptive Statistics, Mean Comparisons and Correlations}

To verify the difference of main factors (attentiveness in science class, scientific attitude, creative personality), we calculated the mean, the standard deviation (see table 6) and implemented the independent sample $t$-test (see Table 7).

Table 6. Mean and standard deviation depending on gender

\begin{tabular}{lcccc}
\hline Variable & Gender & $\mathrm{N}$ & $\mathrm{M}$ & $\mathrm{SD}$ \\
\hline Attentiveness in Science class & Boys & 101 & 3.99 & .76 \\
\cline { 2 - 5 }$(\mathrm{AS})$ & Girls & 107 & 4.14 & .68 \\
\hline Scientific Attitude & Boys & 101 & 3.70 & .88 \\
\cline { 2 - 5 }$(\mathrm{SA})$ & Girls & 107 & 3.52 & .66 \\
\hline Creative Personality & Boys & 101 & 3.57 & .88 \\
\cline { 2 - 5 }$(\mathrm{CP})$ & Girls & 107 & 3.35 & .67
\end{tabular}

According to the results of the questionnaire, the mean AS value of girls was 0.15 points higher than that of boys and the standard deviation of AS of boys was 0.08 points higher than that of girls. The mean of SA of boys was 0.18 points higher than that of girls and the standard deviation of SA of boys was 0.22 points higher than that of girls. In addition, the mean of SA of boys was 0.22 points higher than that of girls and the standard deviation of SA of boys was 0.21 points higher than that of girls. To recognize whether the above differences were significant or not, we performed an independent sample $t$-test (see table 7). 
Table 7. Mean depending on gender (Independent sample $t$-test)

\begin{tabular}{|c|c|c|c|c|c|c|}
\hline & & \multicolumn{5}{|c|}{$t$-test for Equality of Means } \\
\hline & & $t$ & $d f$ & $\begin{array}{c}P \\
\text { (both-side) }\end{array}$ & $\begin{array}{c}\text { Mean } \\
\text { difference }\end{array}$ & Standard error of difference \\
\hline \multirow{2}{*}{ AS } & $\begin{array}{c}\text { Equal variances } \\
\text { assumed }\end{array}$ & 1.479 & 206.000 & .141 & .14569 & .09848 \\
\hline & $\begin{array}{c}\text { Equal variances } \\
\text { not assumed }\end{array}$ & 1.476 & 203.605 & .141 & .14569 & .09848 \\
\hline \multirow{2}{*}{ SA } & $\begin{array}{c}\text { Equal variances } \\
\text { assumed }\end{array}$ & 1.690 & 206.000 & .092 & .18083 & .10697 \\
\hline & $\begin{array}{c}\text { Equal variances not } \\
\text { assumed }\end{array}$ & 1.677 & 185.111 & .095 & .18083 & .10785 \\
\hline \multirow{2}{*}{$\mathrm{CP}$} & $\begin{array}{c}\text { Equal variances } \\
\text { assumed }\end{array}$ & 2.064 & 206.000 & .040 & .22363 & .10836 \\
\hline & $\begin{array}{c}\text { Equal variances not } \\
\text { assumed }\end{array}$ & 2.048 & 186.515 & .042 & .22363 & .10921 \\
\hline
\end{tabular}

Note. Standard error of difference (Rogers \& Twidle, 2013): dispersal of mean differences caused by sampling error.

The $P$-value of AS and SA were 0.141 and 0.092 respectively, so the mean of AS and SA had no significant difference depending on gender. The $P$-value of CP showed 0.040 , which showed a significant difference depending on gender; however, the CP value of effect size $\left[\mathrm{t}^{2} /\left(\mathrm{t}^{2}+d f\right)\right]$ was just $2.1 \%$. We judged that the mean of $\mathrm{CP}$ depending on gender had a significant difference statistically, but explanation power was low. Therefore, we could define that all factors in this study (AS, SA, and CP) had no significant difference depending on gender.

The result of the above study contradicts the findings of other related studies on children's attention concentration such as the notion that a girl's attention concentration level is higher than a boy's (Kim 2009) and that the scientific attitude of a male student is higher than that of a female student (Kim et al., 1998; Shim, So, Lee, \& Chang, 1999). Conversely, this result is congruent with findings such as that there is no gender difference in scientific attitude (Ahn \& Kang, 2014; Kang \& Oh, 2011; Song \& Kim, 2010) and that there is no gender difference specially in sciences (Hill \& Rogers, 2012). Therefore, the result of this study indicates that there is no need to consider differences due to gender in designing science classes for improving creativity.

\subsection{Relationship between $G E, A S, S A$ and $C P$}

For descriptive analysis and to verify the relation of the factors, Pearson correlation analysis was utilized (see Table 8).

Table 8. Correlation analysis $(\mathrm{N}=208)$

\begin{tabular}{cccc}
\hline & AS & SA & CP \\
\hline AS & 1 & & \\
\hline SA & $.313^{* *}$ & 1 & \\
\hline CP & $.361^{* *}$ & $.707^{* *}$ & 1 \\
\hline
\end{tabular}

Note. ${ }^{* *}$. A coefficient of correlation is significant (both-side) at $\mathrm{p}=0.01$.

Correlation between CP, AS and SA was significant at $\mathrm{p}=0.01$, also correlation of SA-CP indicated better correlation than AS-SA and AS-CP scores. The values of correlation coefficient SA-AS, AS-CP and SA-CP were $0.313,0.361$ and 0.707 respectively. Correlations between the three factors were relatively high. In order to obtain an intuitive grasp of the correlation coefficient, the SPLOM (scatterplot matrices) of main factors was used for analysis (see Figure 2). 


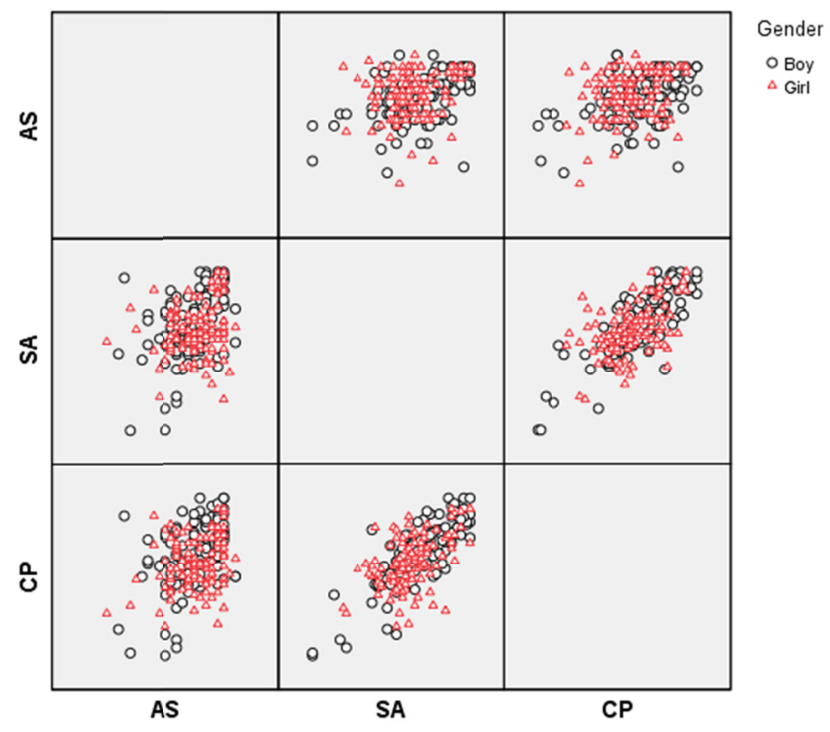

Figure 2. SPLOM of Main factors depending on gender $(.313 \leq \mathrm{r} \leq .707)$

SA-AS and AS-CP had moderate correlation and a plain linear structural relation. SA-CP had high correlation and a strong linear structural relation. Considering the above results, we tried to illuminate the cause-and-effect relationship. Even though only individual factors could be measured, teachers could predict the other factors because SA, AS, and CP evinced positive correlation with each other. Through this method, teachers could better design differentiated science education programs with the ability to comprehend students' characters efficiently.

\subsection{Model Testing}

To clarify the effects between the three factors (CP, AS, and SA), we designed a structural equation model based on theoretical hypothesis (see figure 1, table 1). However, the model based on theoretical hypothesis was inadequate for this study; model fit of the model was insignificant (see table 9). For that reason, we trimmed the prototype model, thus we acquired an adequate, significant model.

Table 9. Goodness of model fit

\begin{tabular}{lccc}
\hline Index & Criterion & Theoretical model & Trimmed model \\
\hline Chi-square (p-Value) & $\mathrm{p}>0.05$ & $7.348(0.025)$ & $2.646(0.104)$ \\
\hline$x^{2} / d f$ & $2<x^{2} / d f<5$ & 3.674 & 2.646 \\
\hline RMSEA & RMSEA $<0.08$ & 0.112 & 0.078 \\
\hline CFI & approaches 1 & 0.969 & 0.991 \\
\hline PNFI & approaches 0 & 0.320 & 0.164 \\
\hline
\end{tabular}

Note. RMSEA (Root Mean Square Error of Approximation), CFI(Comparative Fit Index), PNFI(Parsimony Normed Fit Index).

The maximum likelihood method was employed for model fitting to analyze the structural model. In addition, fitness of the model was assessed by $x^{2}, x^{2} / d f$, RMSEA (above Absolute fit index), CFI (incremental fit indexes) and PNFI (parsimony adjusted index). A chi-square value is the degree of difference between the expected and observed covariance matrices. The probability level must be greater than 0.05 when chi-square is close to zero (Suhr, 2006). $x^{2} / d f$ recommended using ratios from 2 to 5 indicate a reasonable fit (Marsh \& Hocevar, 1985). A value of about 0.08 or less for the RMSEA would present a reasonable error of approximation and acceptable model fit below 0.1 (Browne, Cudeck, Bollen, \& Long, 1993). The obtained value was 2.646. The Comparative Fit Index (CFI) indicates the discord function adjusted for sample size. CFI, which is incremental, fit indexes, ranges from zero to one with a larger value presenting a better model fit. Values above 0.90 show acceptable 
model fit (Hu \& Bentler, 1999). The obtained value was 0.991. The PNFI is the result of compromising the strict standard of the NFI; this index ranges from 0 to 1 , which is parsimonious fit index, with smaller values presenting a better fit (James, Mulaik, \& Brett, 1982). The obtained value was 0.164 .

Therefore, the trimmed model was a better and more significant model than the theoretical model.

\subsection{Trimmed Structural Model (AAC Model) Analysis}

A new path (from GE to SA) was included in the structural model (see Figure 3). This means that gender influenced to scientific attitude significantly in contrast to the previous literature, which claimed that the gender had not influenced to scientific attitude (Ahn \& Kang, 2014; Song \& Kim, 2010).

$12 \%$

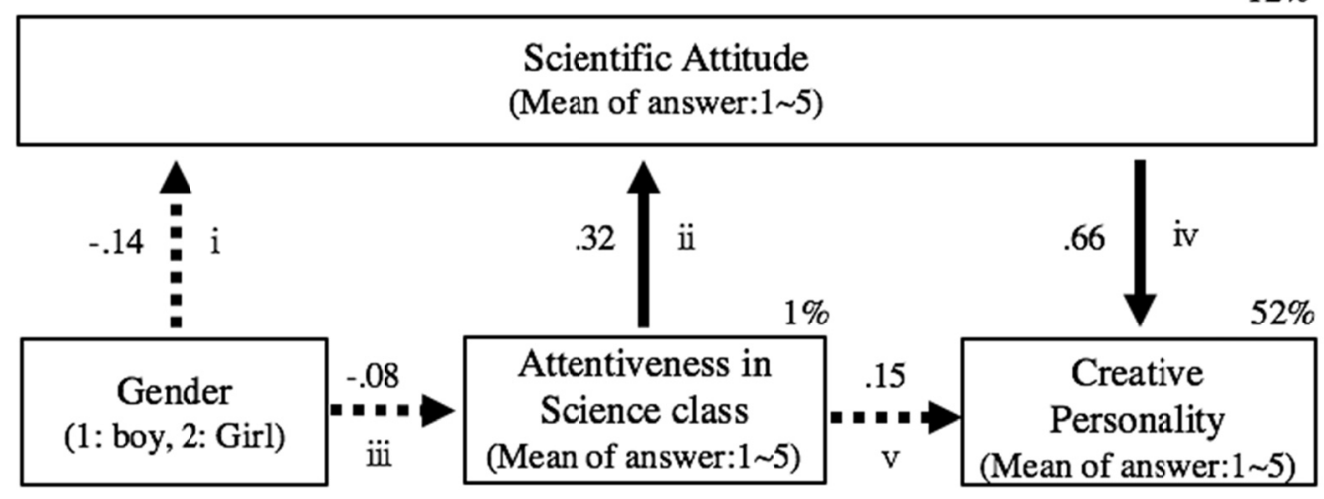

Figure 3. Structural model (AAC model)

We encoded GE with a value of one for boys and a value of two for girls. The mean of CP, AS, and SA got from one to five points. So we calculated the mean of respondent using the value of mean for analysis.

Table 10. Analysis of structural model (AAC model)

\begin{tabular}{|c|c|c|c|c|c|}
\hline Path & $\begin{array}{l}\text { Standardized path } \\
\text { coefficient (direct) }\end{array}$ & Interpretation & & & Explanation power \\
\hline $\mathrm{i}$ & -.14 & Girl & $\rightarrow$ & Mean of SA -0.14 & SA explained $12 \%$ \\
\hline ii & .32 & Mean of AS +1 & $\rightarrow$ & Mean of SA +0.32 & SA explained $12 \%$ \\
\hline iii & -.08 & Girl & $\rightarrow$ & Mean of AS -0.08 & AT explained $1 \%$ \\
\hline iv & .66 & Mean of SA +1 & $\rightarrow$ & Mean of $\mathrm{CP}+0.66$ & $\mathrm{CP}$ explained $52 \%$ \\
\hline $\mathrm{v}$ & .15 & Mean of AS +1 & $\rightarrow$ & Mean of $\mathrm{CP}+0.15$ & CP explained $52 \%$ \\
\hline
\end{tabular}

Note. Those below .10 were considered negligible, those between .10 and .15 were considered relatively small, those between .15 and .25 were moderate in their influence, those above .25 were large in their influence (Keith, 1993).

Gender presents a relatively small influence to SA (see i ). However, SA explained just $12 \%$ of the variation, so we judged that the influence was negligible. Also, we analyzed that Gender scarcely influences AS (see iii). Just referring to path-coefficient, AS presented a large influence to SA (see ii). However, explanation power was just $12 \%$, so the degree of influence from AS to SA was not necessarily large. We judged that SA exhibited the largest influence to CP (see iv) and AS presented a moderate influence to CP (see v). These results imply that teachers should implement science classes focusing on the sustained concentration of students because the ultimate prediction factor was AS among AS, SA, and CP

\subsection{Decomposition of Effect (Direct, Indirect Effect)}

The effect in Path Analysis could dichotomize, which can be divided into direct/indirect path coefficients (see 
Table 11). Because the terminal goal was to find influence of factors on $\mathrm{CP}$ in the AAC model, we elicited the relationship (direct/indirect PC) to explain CP.

Table 11. Decomposition of effects in estimate model (standardized)

\begin{tabular}{ccccc}
\hline \multirow{2}{*}{ Predictor } & Criterion & \multicolumn{3}{c}{ Effect } \\
\cline { 2 - 5 } & & Direct PC & Indirect PC & Total PC \\
\hline Gen & $\mathrm{CP}$ & & -.065 & -.065 \\
\hline AS & $\mathrm{CP}$ & .154 & .213 & .368 \\
\hline SA & $\mathrm{CP}$ & .659 & & .659 \\
\hline
\end{tabular}

The GE presents a small direct influence to CP (-.065). The AS presented the largest influence to CP (.368), and indirect influence (.213) was larger than direct influence (.154); AS influenced SA (mediator variable) first, and then SA influenced CP. SA exhibited the largest direct influence to CP (.659).

The above results imply that teachers should consider the AS as well as the SA to enhance creative personality in the science classroom. The AS directly influence to SA was relatively small, but AS enhanced the SA, and consecutively SA enhanced the CP.

\section{Discussion}

\subsection{Implications}

In this study, subjects' scientific attitude and attentiveness were quantified and measured via instrument to scrutinize how these factors affect elementary students' creativity. The empirical findings induced following implications.

First, the t-test analysis confirmed that gender of the subject does not have an effect on subject's attentiveness in science class (AS), scientific attitude (SA) nor creative personality (CP), in spite of many reported connections between gender and those variables (Kim, 2009). Findings also implied evidences against Kim's claim of male students demonstrating higher scale of positive attitudes (Kim et al., 1998; Shim, So, Lee, \&Chang, 1999), and Gralewski's (2013) claim of male students having higher degree of creativity. Also, the factor analysis confirmed that the gender factor did not or hardly ever influenced attentiveness in science class, scientific attitude, or creative personality. More studies with similar result would be needed in order to close this matter conclusively. As of now, this study suggests that the gender factor has statistically insignificant influence on one's process of learning science.

Second, the correlation between scientific attitude and creative personality came out to be stronger than that of attentiveness in science class and creative personality. The finding was reassured by simulations through structural equation model designed to clarify the effect of these factors. Scientific attitude has significant influence on students' creative personality, while attentiveness in science class influences student creativity both by (i) a weak direct relationship and (ii) a moderate indirect relationship by the medium (scientific attitudes). Considering the fact that attentiveness affects creativity development both directly and indirectly, we do not consider it as a trivial factor in creativity education despite of its comparably smaller contribution. This is because attentiveness in science class is the crucial predication factor to scientific attitude which in turn affects creativity. In this light, while developing creativity enhancement programs, we need to be careful to embrace the whole 3-step relationships. Our understanding of the critical factors on students' creativity would help us to grasp the characteristics of creative students' literacy. We believe that the development of creativity education programs based on these factors would be very effective for forming students' creative personality.

On the contrary to the prevalent ideas that creative people generally possess low or broad attentiveness (Eysenck, 1993; Mendelsohn, 1976), the findings suggested a different interpretation on how creativity occurs. In this research the degree of student creativity varied in a positive and linear relationship with attentiveness in science class. Attentive students are more likely to be creative in specific learning areas. In the same light, the literature has claimed that student attentiveness in mathematics classes affected both achievement and attitudes toward mathematics (Lee, 2003; Moon, 2008). Learners with a higher degree of creative potential are also likely to control their attentiveness (Vartanian, 2009). Attentiveness in various subject areas is correlated to student performance in creative activities (Kasof, 1997; Mendelsohn, 1976).

\subsection{Further Questions}

How can student attentiveness be implemented in a creative education program? Since the directional 
relationship has been revealed to function between attentiveness and creativity, educational programs that promote student attentiveness should be developed and examined in various subject areas among target students in order to confirm any enhancement in student creativity. On the grounds of such empirical outcomes of the attentiveness-creativity programs, more factors or constructs that are believed to influence student creativity should be tested in advanced structural equation models in search of the most effective triggers of student creativity: self-efficacy (Bae \& Lee, 2000; Kim et al., 2007), family background (Sung, 2004; Sung \& Kim, 2011), emotional intelligence (Park \& Yoon, 2004), and motivation (Kim et al., 2007).

Furthermore, results of this study induced that the general model of creativity could be applied to creativity in a science education context. Among the parts of the componential creativity model (Urban, 1995; Urban \& Cho, 1996), the affective domain of creativity (attentiveness, task commitment, motivation, openness and intolerance for ambiguity) had shown dynamic interaction with each other in science class. Attentiveness and task commitment constitutes attentiveness in science class, while motivation, openness and intolerance for ambiguity were the components of scientific attitude. Attentiveness and task commitment influenced motivation, openness and intolerance in the dynamic interaction. Furthermore, according to this study, improving attentiveness and task commitment in science class promotes a high-degree of motivation and a high-level of openness in science class that improves student creativity.

Further research is needed to make application of these empirical findings. For example, Urban (1995) proposed an affective domain of creativity as well as a cognitive domain of creativity such as divergent thinking and behavior, general knowledge and base of thinking skills, and knowledge basis of the domain and domain-relevant. There has still been a lack of research on the cognitive domain of the componential creativity model in science class. Research on the cognitive domain of creativity is needed for elaborating a cognitive creativity model for science class.

\section{References}

Ahn, K. J., \& Kang, K. H. (2014). The Relationship among High School Students' Gender, Academic Track, Metacognition and Scientific Attitude. Journal of Science Education, 38(2), 257-269. https://doi.org/10.21796/jse.2014.38.2.257

Amabile, T. (1989). Growing up creative: nurturing a lifetime of creativity. New York: Crown.

Anderson, J. R. (1982). Acquisition of cognitive skill. Psychological review, 89(4), 369. https://doi.org/10.1037/0033-295X.89.4.369

Bae, J. S., \& Lee, Y. M. (2000). The Relationships between Self-Efficacy, Creative Personality and Creativity of the Elementary School Students. The Journal of Elementary Education, 13(2), 43-61.

Bandura, A. (1995). Self-efficacy in changing societies. Cambridge university press. https://doi.org/10.1017/CBO9780511527692

Becker, G. S. (2009). Human capital: A theoretical and empirical analysis, with special reference to education. University of Chicago Press.

Boden, M. (2001). Creativity and knowledge. Creativity in education, 95-102.

Browne, M. W., Cudeck, R., Bollen, K. A., \& Long, J. S. (1993). Alternative ways of assessing model fit. Sage focus editions, 154, 136-136.

Cho, M. A. (2006). A Study on the Effect of Reading Instruction on the Creative Ability and the Self-Directed Learning Ability. Journal of The Korean Society for Library and Information science, 40(3), 53-71. https://doi.org/10.4275/KSLIS.2006.40.3.053

Chung, C. H., \& Park, Y. B. (2004). The Effectiveness of the Learning Cycle Model for Science Instruction: Preschool Children's Creativity and Scientific Problem Solving Ability. The Korean Journal of Child Studies, 25(3), 1-14.

Couturier, L. C., Mansfield, R. S., \& Gallagher, J. M. (1981). Relationships between humor, formal operational ability, and creativity in eighth graders. The Journal of Genetic Psychology, 139(2), 221-226. https://doi.org/10.1080/00221325.1981.10534157

Csikszentmihalyi, M. (1988). Motivation and creativity: Toward a synthesis of structural and energistic approaches to cognition. New Ideas in Psychology, 6(2), 159-176. https://doi.org/10.1016/0732-118X(88)90001-3

Csikszentmihalyi, M. (1990). Flow: the psychology of optimal experience (1st ed.). New York: Harper \& Row. 
Csikszentmihalyi, M. (1996). Creativity: flow and the psychology of discovery and invention (1st ed.). New York: Harper Collins Publishers.

Csikszentmihalyi, M. (1999). 16 Implications of a Systems Perspective for the Study of Creativity Handbook of creativity (pp. 313-335). Cambridge University Press.

Eysenck, H. J. (1993). Creativity and personality: Suggestions for a theory. Psychological Inquiry, 4(3), 147-178. https://doi.org/10.1207/s15327965pli0403_1

Feldhusen, J. F., Speedie, S. M., \& Treffinger, D. J. (1971). The Purdue creative thinking program: Research and evaluation. NSPI Journal, 10(3), 5-9. https://doi.org/10.1002/pfi.4180100304

Getzels, J. W., \& Jackson, P. W. (1962). Creativity and intelligence: Explorations with gifted students.

Gralewski, J., \& Karwowski, M. (2013). Polite Girls and Creative Boys? Students' Gender Moderates Accuracy of Teachers' Ratings of Creativity. The Journal of Creative Behavior, 47(4), 290-304. https://doi.org/10.1002/jocb.36

Hadzigeorgiou, Y., Fokialis, P., \& Kabouropoulou, M. (2012). Thinking about Creativity in Science Education. Creative Education, 3(5), 603-611. https://doi.org/10.4236/ce.2012.35089

Hao, N., Ku, Y., Liu, M., Hu, Y., Bodner, M., Grabner, R. H., \& Fink, A. (2016). Reflection enhances creativity: Beneficial effects of idea evaluation on idea generation. Brain and cognition, 103, 30-37. https://doi.org/10.1016/j.bandc.2016.01.005

Hill, T. P., \& Rogers, E. (2012). Gender Gaps in Science: The Creativity Factor. The Mathematical Intelligencer, 34(2), 19-26. https://doi.org/10.1007/s00283-012-9297-9

Hoelter, J. W. (1983). The analysis of covariance structures goodness-of-fit indices. Sociological Methods \& Research, 11(3), 325-344. https://doi.org/10.1177/0049124183011003003

Hu, L. T., \& Bentler, P. M. (1999). Cutoff criteria for fit indexes in covariance structure analysis: Conventional criteria versus new alternatives. Structural equation modeling: a multidisciplinary journal, 6(1), 1-55. https://doi.org/10.1080/10705519909540118

James, L. R., Mulaik, S. A., \& Brett, J. M. (1982). Causal analysis: Assumptions, models, and data (Vol. 1). SAGE Publications, Incorporated.

Jyung, U. Y., Kim, B. W., Song, B. K., Choi, D. S., Lee, J. B., Kim, E. S., Kim, B. K. (2012). The Effect of Vocation Experience Activity on Elementary School Students' Career Development, Academic Motive, Creativity and Sociality. The Journal of Career Education Research, 25(3), 1-17.

Kang, S. T., \& Oh, H. S. (2011). The Influence of Science Camp on Changing the Elementary and Middle Students' Attitude toward Science - Focusing on Jeju Beach Science Camp. Research of education, 51, 155-180. https://doi.org/10.17253/swueri.2011.51..006

Kasof, J. (1997). Creativity and breadth of attention. Creativity Research Journal, 10(4), 303-315. https://doi.org/10.1207/s15326934crj1004_2

Keith, T. Z. (1993). Causal influences on school learning. Analytic methods for educational productivity, 3 , 21-47.

Kim, E. A., Chung, O. B., \& Chung, S. H. (2007). An Analysis of the Relationship between Intrinsic Motivation, Self-Efficacy, and Creativity of Children focusing on Sex and Age. Journal of educational studies, 38(2), 23-47.

Kim, E. S., Kwon, Y. S., \& Lee, K. J. (2011). The Effect of Science Activity Activating Spatial Ability on Elementary School Students' Spatial Ability and Creativity Improvement. Journal of Korean Elementary Science Education, 30(2), 178-188.

Kim, H. N., Chung, W. H., \& Jeong, J. W. (1998). National Assessment System Development of Science-Related Affective Domain. Journal of The Korean Association for Research In Science Education, 18(3), 357-369.

Kim, K. Y. (2009). Young Children's Social Competence with Attention Ability, Behavioral Problems and Emotional Competence. Journal of Far East Social Welfare, 5, 81-101.

Kim, M. S., \& Han, K. S. (2008). An Analysis of Structural Equation Model on the Scientific Problem Finding Ability of the Scientifically Gifted Based on Science Related Attitude, Motivation, and Self-Regulation Learning Strategy. Journal of gifted talented education, 18(1), 23-52. 
Kim, S. H. (2006). Development and Validation of Learning Concentration Scale. The Korea Journal of Counseling, 7(4), 1039-1054.

Lee, M. H. (2003). Effects of the flow level increasing on mathematical achievement and mathematical attitude (Unpublished master's thesis). Graduate School of Korea National University of Education.

Lee, N. J., \& Paik, S. H. (2014). Research on 'Flow' and Creativity as Observed in the Daily Lives of Science-Gifted Students. Journal of the Korean Association for Research In Science Education, 34(2), 147-153. https://doi.org/10.14697/jkase.2014.34.2.0147

Lee, S. E. (2007). Young Children's Behavioral Problems and Attention Ability by Parenting Attitude. The Korean Journal of Child Studies, 28(2), 71-89.

Lieberman, J. N. (1965). Playfulness and divergent thinking: An investigation of their relationship at the kindergarten level. The Journal of Genetic Psychology, 107(2), 219-224. https://doi.org/10.1080/00221325.1965.10533661

Marsh, H. W., \& Hocevar, D. (1985). Application of confirmatory factor analysis to the study of self-concept: First-and higher order factor models and their invariance across groups. Psychological bulletin, 97(3), 562. https://doi.org/10.1037/0033-2909.97.3.562

Mehrinejad, S. A., Rajabimoghadam, S., \& Tarsafi, M. (2015). The Relationship between Parenting Styles and Creativity and the Predictability of Creativity by Parenting Styles. Procedia-Social and Behavioral Sciences, 205, 56-60. https://doi.org/10.1016/j.sbspro.2015.09.014

Mellou, E. (1996). Can Creativity be Nurtured in Young Children? Early Child Development and Care, 119(1), 119-130. https://doi.org/10.1080/0300443961190109

Mendelsohn, G. A. (1976). Associative and attentional processes in creative performance1. Journal of Personality, 44(2), 341-369. https://doi.org/10.1111/j.1467-6494.1976.tb00127.x

Moon, I. S. (2008). The Effects of the Flow study program on Mathematical Achievement and Mathematical Attitude (Unpublished master's thesis). Busan National University of Education.

Moravcsik, M. J. (1981). Creativity in science education. Science Education, 65(2), 221-227. https://doi.org/10.1002/sce.3730650212

Mourgues, C., Tan, M., Hein, S., Elliott, J. G., \& Grigorenko, E. L. (2016). Using creativity to predict future academic performance: An application of Aurora's five subtests for creativity. Learning and Individual Differences. https://doi.org/10.1016/j.lindif.2016.02.001

NCIC (1987). The National Science Curriculum. Seoul: National Curriculum Information Center. Retrieved from http://www.ncic.go.kr/

NGSS Lead States (2013). Next Generation Science Standards: For States, By States. Washington, DC: The National Academies Press.

Nickerson, R. S. (1999). 20 Enhancing Creativity. Handbook of creativity, 392.

Paramitha, A., \& Indarti, N. (2014). Impact of the Environment Support on Creativity: Assessing the Mediating Role of Intrinsic Motivation. Procedia - Social and Behavioral Sciences, 115, 102-114. https://doi.org/10.1016/j.sbspro.2014.02.419

Park, S. B., \& Yoon, J. L. (2004). The Relationship between Creativity, Emotional Intelligence, and Academic Achievements in the Elementary School Children. Journal of educational psychology, 18(4), 199-216.

Politis, J., \& Houtz, J. C. (2015). Effects of Positive Mood on Generative and Evaluative Thinking in Creative Problem Solving. SAGE Open, 5(2), 2158244015592679. https://doi.org/10.1177/2158244015592679

Prabhakaran, R., Green, A. E., \& Gray, J. R. (2014). Thin slices of creativity: Using single-word utterances to assess creative cognition. Behavior research methods, 46(3), 641-659. https://doi.org/10.3758/s13428-013-0401-7

Rogers, L., \& Twidle, J. (2013). A pedagogical framework for developing innovative science teachers with ICT. Research in Science \& Technological Education, 31(3), 227-251. https://doi.org/10.1080/02635143.2013.833900

Runco, M. A. (2014). Creativity: Theories and themes: Research, development, and practice. Elsevier.

Scott, G., Leritz, L. E., \& Mumford, M. D. (2004). The effectiveness of creativity training: A quantitative review. 
Creativity Research Journal, 16(4), 361-388. https://doi.org/10.1080/10400410409534549

Shim, K. C., So, K. H., Lee, H. U., \& Chang, N. K. (1999). Research Articles: Study on the Attitude toward Science of Science Gifted and Talented and General Middle School Students. Biology Education, 27(4), 368-375.

Shin, M. S. (2010). A Study on the Development of Creative Personality Inventory for the Identification of the Gifted Elementary School Children (Unpublished doctoral dissertation). Graduate School of Korea National University of Education.

Song, K. (2014). The Relation of Intelligence, Self-esteem, Mathematical Attitudes, and Scientific Attitudes of Gifted Students from Low-income Families. Journal of Gifted/Talented Education, 24(6), 1039-1051. https://doi.org/10.9722/JGTE.2014.24.6.1039

Song, Y. W., \& Kim, B. K. (2010). The Development of an Instrument for Scientific Attitudes in School, Home and Social Situations and Selection of Scientific Attitude Elements. Journal of The Korean Association for Research in Science Education, 30(4), 375-388.

Sternberg, R. J., \& Williams, W. M. (1996). How to develop student creativity. ASCD.

Suhr, D. D. (2006). Exploratory or confirmatory factor analysis? SAS Institute Cary.

Sung, E. H. (2004). Relationships between the mothers' internal-external locus of control, creative home environment and daughters' and sons' creative personality. The Korean Journal of Developmental Psychology, 17(3), 79-93.

Sung, E. H., \& Kim, N. R. (2011). The Relationships between family income, creativity and academic achievement. The Journal of creativity education, 11(1), 5-20.

Tarver, S. G., Buss, B. R., \& Maggiore, R. P. (1979). The relationship between creativity and selective attention in LD boys. Learning Disability Quarterly, 2(1), 53-59. https://doi.org/10.2307/1510839

Thomas, N. G., \& Berk, L. E. (1981). Effects of School Environments on the Development of Young Children's Creativity. Child Development, 52(4), 1153-1162. https://doi.org/10.2307/1129501

Torrance, E. P. (1972). Can We Teach Children to Think Creatively?

Torrance, E. P. (1995). Insights about creativity: Questioned, rejected, ridiculed, ignored. Educational Psychology Review, 7(3), 313-322. https://doi.org/10.1007/BF02213376

Treffinger, D. J., Isaksen, S. G., \& Stead-Dorval, K. B. (2006). Creative problem solving: An introduction. Prufrock Press Inc.

Urban, K. K. (1995). Creativity-A componential approach. In Post conference China meeting of the 11th world conference on gifted and talented children. Beijing, China, August (pp. 5-8).

Urban, K. K., \& Cho, S. H. (1996). Creativity-a Componential Approach. Journal of educational studies, 24, 5-27.

Vartanian, O. (2009). Variable attention facilitates creative problem solving. Psychology of Aesthetics, Creativity, and the Arts, 3(1), 57-59. https://doi.org/10.1037/a0014781

Weisberg, R. (1986). Creativity: Genius and other myths. WH Freeman/Times Books/Henry Holt \& Co.

Workman, E. A., \& Stillion, J. M. (1974). The relationship between creativity and ego development. The Journal of psychology, 88(2), 191-195. https://doi.org/10.1080/00223980.1974.9915728

Yoo, C. E., \& Lee, K. S. (2012). The Impact of Developing Creativity of Expressive Activities Applying Multiple Intelligences Theory for Students in Elementary School. The journal of education, 32(1), 25-36.

Zhu, W., Chen, Q., Tang, C., Cao, G., Hou, Y., \& Qiu, J. (2016). Brain structure links everyday creativity to creative achievement. Brain and Cognition, 103, 70-76. https://doi.org/10.1016/j.bandc.2015.09.008

\section{Copyrights}

Copyright for this article is retained by the author(s), with first publication rights granted to the journal.

This is an open-access article distributed under the terms and conditions of the Creative Commons Attribution license (http://creativecommons.org/licenses/by/4.0/). 